Flüssigkeits-Festkörper-Chromatographie, FlüssigkeitsGel-Chromatographie und. Flüssigkeits-FlüssigkeitsChromatographie zu unterscheiden, und gelangte damit zu einem, zuverlässigen Wegweiser für den weiteren Ausbaú der chromatographischen Methoden. Als Neuestes hat MarTin in logischer Entwicklung die FlüssigkeitsGas-Chromatographie eingeführt und damit der analytischen Chemie ein weiteres wundervolles Werkzeug in die Hand gegeben.

M. BRENNER

\section{Selman A. Waksman}

The Nobel Prize in Physiology and Medicine for 1952 was awarded to Dr. Selmai A. Waksman for his work in the discovery and development of streptomycin as "the first effective antibiotic found for use against tuberculosis". Aside from the obviously great.medical advance this discovery represents, the contribution of Dr. WaksmaN is equally significant for the development of the entire field of antibiotic research.

The work of Dubos in 1939 on the'tyrothricin complex produced by a bacterium, Bacillus brevis, marked the beginning of the recent advances in our knowledge of antibiotics. The work of the Oxford group, headed by FLOREY and CHAIN, in 1940 on the production of penicillin (discovered by Fleming in 1929) by a fungus, Penicillium notatum, set the precedent for the use of antibiotics as chemotherapeutic agents in the treatment of infectious diseases in man. It was, however, the investigations of Dr. WAKSMAN in 1940 on antibiotics produced by soil actinomycetes that laid the basis for much of the successful discovery of antibiotics which followed. Beginning with actinomycin and streptothricin, the extensive screening of soil actinomycetes by Dr. WaksMAN led to the discovery of streptomycin in 1944. Since then, the most widely applied antibiotics have been isolated from soil actinomycetes, notably chloramphenicol, aureomycin and terramycin.

The discovery of streptomycin by Dr. Waksman can best be appreciated when understood within the framework of his earlier scientific research. A definite developmental relationship exists between his many years of research in soil microbiology and his more recent investigations of antibiotics. The success of his antibiotic research was partly made possible by many. years of basic research. in soil microbiology. The discovery of streptomycin, regarded from a perspective of his entire scientific career, may be considered as a side product of his earlier work.

Dr. WaKsman was born in Russia in 1888 and received his early education there. He came to America in 1910 with a desire to advance his knowledge and training in biological science. It was under the inspiring influence of Dr. JAсов G. LipmaN of the New Jersey Agricultural Experiment Station at Rutgers University that he first became interested in. soil microbiology. There, he obtained his B.S. degree in 1915 and his M.S. degree in 1916. After obtaining his Ph.D. degree in biochemistry in 1918 at the University of California, he returned to Rutgers University to become Microbiologist and Lecturer in Soil Microbiology at the New Jersey Agricultural Experiment Station. He was elevated to associate professorship in 1924, to full professorship in 1930, and became head of the Department of Microbiology in 1942. Throughout these years, Dr. WAksman and his associates embarked on an extensive program of soil microbiological research. The microbiological population of the soil was investigated, concentrating on the neglected groups: protozoa, fungi and actinomycetes. The role of these microorganisms in soil processes was studied as well as general microbiological activities in the soil, such as the decomposition of organic matter. The oxidation of sulfur to sulfate by Thiobacillus thiooxidans and its application to soil processes was an important contribution. Investigations of the chemical nature of soil humus and the role of soil microorganisms in its formation and decomposition, and publication of a book, Humus $(1936,1938)$, constituted major advances in our knowledge of this subject. Dr. Waksman's book, Principles of Soil Microbiology $(1927,1932)$, is considered to be the authoritative text in the field of soil microbiology.

By 1937, Dr. Waksmax's attention turned to a study of associative and antagonistic effects of microorganisms based on his experiences with mixed microbial populations in the soil. When the antibiotic research was begun around 1940 , it was natural for him to investigate "the soil as a source of microorganisms antagonistic to diseaseproducing bacteria". The last key factor in the sequence of events leading to the discovery of streptomycin was the selection of the actinomycetes as possible producers of antibiotic substances. It is interesting to note that as early as 1919 Dr. WAKsman had already published several comprehensive articles on the occurrence of actinomycetes in the soil, outlining a classification based not only on morphological characteristics but on cultural characteristics as well. He returned to this subject in 1940, when the actinomycetes were assuming a new found importance, with the publication of a classification scheme for these microorganisms. This scheme formed the basis for the final classification of the actinomycetes published in 1943 by WAKSMAN and HENRICI which is now the officially accepted classification as appears in Bergey's Manual of Determinative Bacteriology. It was his preoccupation, throughout the years, with this relatively unknown group of microorganisms which equipped him so well to investigate them as a source of antibiotics. The often observed inhibition of bacteria, actinomycetes and fungi by many species of soil actinomycetes (genus Streptomyces), as well as the relatively large numbers of actinomycetes in a mixed competitive microbial population in soil, where pathogenic organisms do not survive, naturally led him to the selection of these microorganisms for the investigation of antibiotic production. This group of microorganisms has proved to be the most fruitful as a source of antibiotics which have found successful therapeutic application. In Dr. WAKsMAN's laboratories alone, numerous actinomycete antibiotics, including anti-fungal and anti-viral agents, have been isolated since streptomycin. Most have been of academic interest and one, neomycin, is finding increasing therapeutic use today.

The honor bestowed upon Dr. Waksman by the award of the Nobel Prize is a fitting recognition of many years of outstanding research in soil microbiology, culminating in antibiotic research and the discovery of streptomycin. W. Segat

\section{Gorrigendum}

W. BEJDL, Besprechung des Buches Atlas der normalen Histologie und mikroskopischen Anatomie des Menschen (Exper. 8, Fasc. 10, 398 [1952]).

Der Referent macht uns darauf aufmerksam, dass der eine Autor richtigerweise E. v. HERRATH heisst und nicht E. v. Errath. 